\title{
The evaluation of the effect of vitamin $D$ replacement on the symptoms of carpal tunnel syndrome in patients with low vitamin D levels
}

\author{
Ayse Gul Korkut ${ }^{1}$, Sebnem Koldas Dogan², Meral Bilgilisoy Filiz² ${ }^{2}$ Naciye Fusun \\ Toraman $^{2}$ \\ ${ }^{l}$ Department of Physical Medicine and Rehabilitation, Kepez State Hospital, Antalya, Turkey \\ ${ }^{2}$ Department of Physical Medicine and Rehabilitation, Health Science University, Antalya Training and Research \\ Hospital, Antalya, Turkey
}

\section{ABSTRACT}

Aim: To evaluate the effect of vitamin D replacement on carpal tunnel syndrome (CTS) symptoms and signs in CTS patients with low vitamin D levels.

Methods: This study was designed prospective observably. The patient population was admitted to the EMG (electromyography) laboratory in a tertiary hospital's Physical Medicine and Rehabilitation Department between 1 January and 31 July 2018. Initially, 55 patients were included in the study. The patients were categorized into two groups as group $1(<10 \mathrm{ng} / \mathrm{ml})$ and group $2(10-20 \mathrm{ng} / \mathrm{ml})$ according to the vitamin D levels. A total of 39 patients and 63 wrists, 17 patients in group 1 (28 wrists) and 22 patients in group 2 (35 wrists), were included in the analysis.

Results: There was a statistically significant decrease in visual analogue scale and quick arm-shoulder-hand disability score in two groups when compared before treatment. In two groups, there was a significant improvement in grip and pinch strength after treatment. At the same time, after treatment we showed that there was a statistically significant increase in median nerve sensory amplitude in two groups. The increase in median nerve sensory velocity was significant in group 2 whereas it was not statistically significant between group 1 vs group 2.

Conclusions: Vitamin D replacement can improve symptoms, functional status and electrophysiological findings in CTS patients with low vitamin D levels.

Key words: Carpal tunnel syndrome, vitamin D, median nerve, neuropathy, visual analog scale, electrophysiology.

$\triangle$ Dr. Ayse Gul Korkut

Department of Physical Medicine and Rehabilitation,

Kepez State Hospital, Antalya, Turkey

E-mail: draysegulkorkut07@gmail.com

Received: 2021-03-12 / Revisions: 2021-04-10

Accepted: 2021-06-20/ Published online: 2021-07-01

\section{Introduction}

Carpal tunnel syndrome (CTS) is characterized by chronic compression of the median nerve through the carpal tunnel at the wrist. Most of the causes are idiopathic but diabetes mellitus (DM), thyroid disease, gout and pregnancy are known as the risk factors [1].

Conservative treatment options for CTS include avoiding repetitive hand activities; splinting; local corticosteroid injections, oral corticosteroid treatment; physical therapy modalities; nerve gliding exercises [2]. Carpal tunnel release surgery is recommended for patients with severe CTS whose symptoms 
have not improved with conservative treatment [3].

Vitamin D (Vit D) is a steroid-like compound that can have hormone-like effects. Despite being known as a vitamin, it is distinguished from other vitamins as it can be synthesized in the body. Serum 25 hydroxyvitamin D $(25(\mathrm{OH}) \mathrm{D})$ levels indicate the adequate Vit D levels[4].

In recent years, the neuroprotective effects of Vit D have been emphasized in the literature. Although the mechanism of this neuroprotective effect has not been fully elucidated yet, Vit D has been shown to have an antioxidant effect and this effect may play a role in preventing neuronal necrosis, and increasing myelinization by reducing the release of free radicals and blocking calcium channels [5]. Animal studies have reported that Vit D has protective effects on neurons and decreases neuronal toxicity and damage [6]. Low level of Vit D levels in CTS are reported in small number of studies however, studies in which evaluating whether CTS symptoms and signs improve after Vit D replacement is limited[1].

In this study it is aimed to evaluate the symptoms and signs of CTS after Vit D replacement in mild-to-moderate CTS patients with low Vit D levels. The study hypothesizes that both the clinical and electrophysiological findings in CTS cases with low Vit D levels will improve in the third month following the initiation of Vit D replacement therapy.

\section{Materials and methods}

This research was designed as a single-center prospective observational study. An informed consent form was signed by and obtained from all patients who volunteered to participate in the study. The study was approved by the Ethics Committee of Health Sciences University, Clinics of Physical Medicine and Rehabilitation with the decision number 5/1, date 08/03/2018, and research number 2018-030.

Vitamin D level $<20 \mathrm{ng} / \mathrm{mL}$ was considered to be low vitamin D level. Patients aged 18-65 years with a VitD level of $<20 \mathrm{ng} / \mathrm{mL}$, who were admitted to the outpatient clinic with CTS symptoms and signs within the period from January 2018 to July 2018, were evaluated in terms of eligibility for the study.

The diagnosis of CTS was clarified based on clinical and electrodiagnostic criteria published jointly by the American Association of Electrodiagnostic Medicine (AAEM), American Academy of Neurology (AAN), and American Academy of Physical Medicine and Rehabilitation (AAPMR) in 2002 [7].

Patients, who met all clinical criteria and had electrophysiological findings supporting median neuropathy at the wrist, were accepted as definite CTS. Among patients, who received the definite CTS diagnosis and were evaluated to be mild-to-moderate CTS based on their electrophysiological findings, were included in the study. Both wrists were considered as separate patients.

Inclusion criteria of the study were being 18-65 years of age, and having mild-to-moderate CTS with a VitD level below $20 \mathrm{ng} / \mathrm{mL}$.

Patients who were $<18$ and $>65$ years old; patients with normal VitD levels; severe or very severe CTS; comorbidities including DM, chronic renal failure, chronic liver disease, thyroid disease, rheumatoid arthritis, systemic lupus erythematosus, scleroderma, gout, polymyositis, dermatomyositis, polyneuropathy, cervical radiculopathy, brachial plexopathy, and thoracic outlet syndrome; vitamin B12 or folic acid deficiency a history of trauma; and previous carpal tunnel surgery were excluded (Figure 1).

The patients were divided into two groups according to their VitD level. In Group 1 


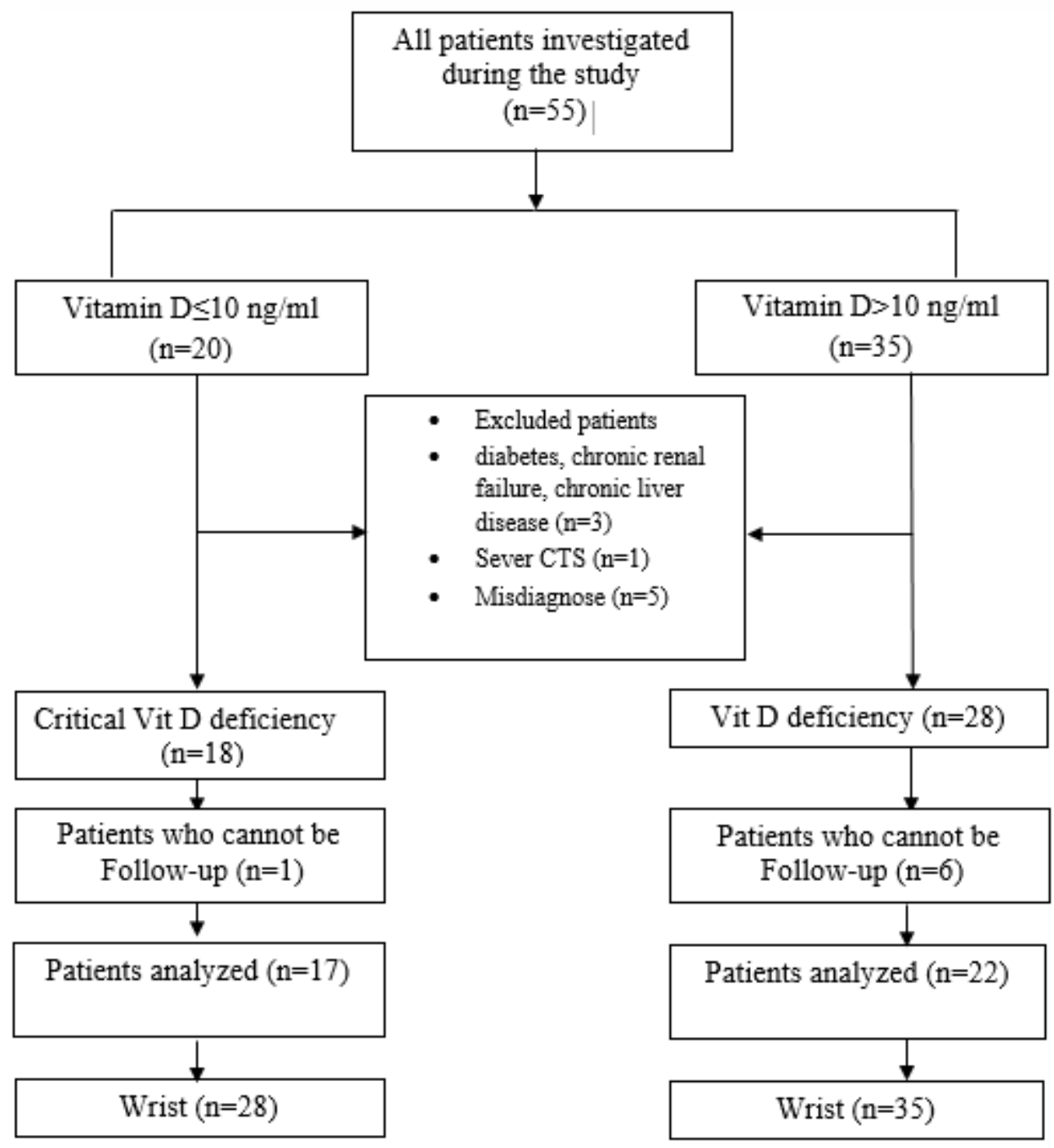

Figure 1. Patient flow chart.

patients with a VitD level of $<10 \mathrm{ng} / \mathrm{mL}$ (Critical VitD deficiency) and in Group 2 patients with a VitD level of $10-20 \mathrm{ng} / \mathrm{mL}$ (VitD deficiency) were included. Splinting is recommended for all patients and VitD replacement therapy were applied in both groups. Cholecalciferol (vitamin D3) were given orally at a loading dose of 50,000 IU/week for eight weeks as VitD replacement therapy. Afterward, the maintenance dose was given as 3000-6000 IU/day.

During the 3-month follow up period, patients did not receive any physical therapy or median nerve injection therapy.

\section{Biochemical analysis}

Laboratory examinations, including a screening analysis of $25(\mathrm{OH}) \mathrm{D}$ levels, were performed using venous blood specimens. All serum 25(OH)D (ng/mL) concentrations were analyzed using electrochemiluminescence immunoassay (ECLIA) technique with LIAISON analyzer (DiaSorin, Stillwater, MN).

\section{Evaluation of peripheral neuropathy and pain}

At baseline sociodemographic characteristics (age, gender, weight, height, occupation, hand dominance, disease duration) of the patients were recorded. (Table 1). The quick disabilities 
of the arm, shoulder, and hand questionnaire (QuickDASH) was used to assess symptom severity, pain, and functional capability in the hand, while the pain intensity was assessed by visual analog scale (VAS). Patients completed these questionnaires at the beginning of the study and in the third month following the initiation of replacement therapy.

\section{Visual analogue scale (VAS)}

Patients were asked to rate their severity of hand or wrist pain on a 10 -cm-long straight line with numbers, ranging from 0 to 10 . Before the application, it was explained that the value 0 represented no pain and the value 10 represented the most severe pain they had ever felt.

\section{Quick disabilities of the arm, shoulder, and} hand questionnaire (QuickDASH)

This self-reported questionnaire was developed by the American Academy of Orthopaedic Surgeons (AAOS) in 1994 based on the model developed by the World Health Organization (WHO). It measures physical function and symptoms of patients suffering from upper extremity problems. The questionnaire contains disability/symptom scale (11 items) and 2 optional scales (work (4 items) and sports/performing arts (4 items)). Each question is scored between 1 and 5. Each subscales ranged between 0 (no disability) and 100 (most severe disability). The reliability and validity of the Turkish version of the questionnaire in patients with CTS was conducted by Koldaş Doğan Ş et al.[8] among patients with CTS. It is completed in about five to seven minutes, with moderate ease of scoring [9].

\section{Measurement of grip and pinch strength}

Grip and pinch strengths were measured at the beginning of the study and at the third month of treatment. An electronic hand dynamometer [Electronic Hand Dynamometer (HS-005), China] was used to measure grip strength whereas finger grip strength was measured using a manual pinchmeter (Sammons Preston, Inc. Bolingbrook, IL 60440-4989). The results were recorded in kilograms $(\mathrm{kg})$. Handgrip strength measurements were performed while the patient was in the sitting position, the arm was in adduction, the forearm was in $90^{\circ}$ flexion and neutral position, and the wrist was in $0-30^{\circ}$ extension and $0-15^{\circ}$ ulnar abduction position. Patients were asked to give full maximum voluntary effort grip [10]. In the test procedure, a total of three measurements were made by taking a break between each measurement for grip and pinch strengths and their averages were recorded $[11,12]$.

\section{Electrophysiological evaluation}

All electrophysiological evaluations were performed using Nihon Kohden Neuropack S1 MEB-9400K EMG Device (Tokyo, Japan). All patients were evaluated electrophysiologically at the beginning of the treatment and at the third month of treatment. All nerve conduction studies were performed by the same physician using bipolar superficial electrodes, the same device, and standard technique, in accordance with the relevant guidelines. Median and ulnar sensory nerve conduction and distal (wrist) and proximal (elbow) motor nerve conduction were studied on the one hand, and median sensory nerve conduction and distal and proximal motor nerve conduction were studied on the other hand $[13,14]$.

\section{Statistical analysis}

Statistical analysis was performed using SPSS version 20.0 software (IBM Corporation, Armonk, NY, USA). Using the G-Power analysis, the sample size was calculated by 
taking the power as $90 \%$, alpha value as 0.05 , and effect value as 0.2 . To the best of our knowledge, there were no studies evaluating Vit D replacement therapy in line with the purpose of this study. Therefore, studies comparing the VAS score and CTS severity of mild-to-moderate CTS patients with low and normal Vit D levels were utilized to calculate the effect value. The Shapiro-Wilk test was used to determine whether the groups followed a normal distribution. Descriptive data were expressed as mean, standard deviation, median, highest and lowest values, frequency, and ratio. The means of variables following normal distribution were compared using Student's ttest. In variables not following a normal distribution, the Wilcoxon signed-rank test was used for dependent groups whereas the MannWhitney $U$ test test was used for independent groups. Chi-Square and McNemar tests were used in categorical variables. A $p$ value of $<0.05$ was considered statistically significant.

Tablo 1. Demographic status of the patients.

\begin{tabular}{|c|c|c|c|}
\hline Parameters & $\begin{array}{l}\text { Group } 1 \text { Critical Vit D } \\
\text { deficiency } \\
(n=17)\end{array}$ & $\begin{array}{l}\text { Group } 2 \\
\text { Vit D deficiency } \\
(n=22)\end{array}$ & $\boldsymbol{P}$ \\
\hline Wrist & 28 & 35 & \\
\hline Age (years) (mean \pm SD) & $47.82 \pm 8,47$ & $46.14 \pm 8,46$ & $0.541^{a}$ \\
\hline \multirow{2}{*}{$\begin{array}{l}\text { Gender }(\mathbf{n}, \%) \\
\quad \text { Female } \\
\text { Male }\end{array}$} & $17(100)$ & $20(90.9)$ & \multirow{2}{*}{$0.202^{b}$} \\
\hline & $0(0.0)$ & $2(9.1)$ & \\
\hline \multirow{3}{*}{$\begin{array}{l}\text { Working status (n, \%) } \\
\text { Work } \\
\text { Not working } \\
\text { Retired }\end{array}$} & $5(29.4)$ & $7(31.8)$ & \multirow{3}{*}{$0.907^{b}$} \\
\hline & $11(64.7)$ & $13(59.1)$ & \\
\hline & $1(5.9)$ & $2(9.1)$ & \\
\hline Length $(\mathrm{cm})($ mean \pm SD) & $158.59 \pm 6.12$ & $159.18 \pm 6,58$ & $0.775^{a}$ \\
\hline Weight (kg) (mean \pm SD) & $72.12 \pm 12.22$ & $70.59 \pm 14.23$ & $0.460^{c}$ \\
\hline BMI $\left(\mathrm{kg} / \mathrm{m}^{2}\right)(\operatorname{mean} \pm$ SD $)$ & $28.49 \pm 5.63$ & $27.62 \pm 4.07$ & $0.580^{a}$ \\
\hline $\begin{array}{l}\text { Symptom time (month) } \\
(\text { mean } \pm \text { SD) }\end{array}$ & $5.65 \pm 2.89$ & $4.59 \pm 2.44$ & $0.177^{c}$ \\
\hline \multirow{2}{*}{$\begin{array}{l}\text { Dominant hand (n, \%) } \\
\text { Right } \\
\text { Left }\end{array}$} & $13(76.5)$ & $19(86.4)$ & \multirow{2}{*}{$0.425^{b}$} \\
\hline & $4(23.5)$ & $3(1.6)$ & \\
\hline \multirow{3}{*}{$\begin{array}{l}\text { Symptomatic hand (n, \%) } \\
\text { Right } \\
\text { Left } \\
\text { Bilaterally }\end{array}$} & $6(35.3)$ & $5(22.7)$ & \multirow{3}{*}{$0.159^{b}$} \\
\hline & $0(0.0)$ & $4(18.2)$ & \\
\hline & $11(64.7)$ & $13(59.1)$ & \\
\hline
\end{tabular}

a; Student T test was used. Mean \pm Standart deviation (SD) was showen. $b$; Chi-square test was used. c; Mann-Whitney U was used. Mean \pm Standart deviation (SD) was showen. 


\section{Results}

At the initial phase of the study, a total of 55 patients meeting the inclusion criteria were included. Nine patients were excluded due to the presence of exclusion criteria and seven patients were excluded from the study because they did not come for post-treatment controls.

A total of 63 wrists were included in the analyses. All of these patients were given Vit D replacement. The patient flow chart is shown in Figure 1. The mean age of the patients was $46.87 \pm 8.39$ years. The symptom duration of the patients was $5.65 \pm 2.89$ and $4.59 \pm 2.44$ months in Group 1 and Group 2, respectively. Demographic characteristics of the patients were given in Table 1

In both groups, Vit D levels were observed to be statistically significantly increased in posttreatment compared to baseline $(\mathrm{p}=0.000$ and $p=0000$ for Group 1 and Group 2, respectively). Similarly, there were statistically significant decreases in VAS scores in both groups after treatment (VAS day/night $p=0.021, p=0.012, p=0.000$, and $p=0.000$ for Group 1 and Group 2, respectively). In both groups, statistically significant decreases were found in the QuickDASH symptom and job subscores measured after treatment compared to pre-treatment $(p=0.000$ and $p=0.002$; $p=0.000$ and $p=0.000$ for Group 1 and Group 2 , respectively). There were also statistically significant differences between groups in terms of grip and pinch strengths after treatment compared to pre-treatment $(p=0.026$ and $p=0.030$ ). At Post-treatment grip strengths of both groups were increased compared to pretreatment values $(p=0.003$ and $p=0.000$ for Group 1 and Group 2, respectively). There was no statistically significant difference in the pinch strengths $(p=0.892$ and $p=0.079$ for Group 1 and Group 2, respectively) between the groups. The rate of patients whose VitD levels returned to normal after treatment was $10.7 \%$ in Group 1 and $22.7 \%$ in Group 2. This improvement rate was found to be statistically significant $(p=0.012$ and $p=0.039$ for Group 1 and Group 2, respectively). The pre and posttreatment values of the pain severity and functional status of the patients were given in Table 2.

Table 2. Comparison between the patients of functional and pain scores before and after vitamin D replacement.

\begin{tabular}{|c|c|c|c|c|c|c|c|c|}
\hline Parameters & $\begin{array}{l}\text { Group 1 } \\
\text { Critical Vit D } \\
(n=17)\end{array}$ & eficiency & $\begin{array}{l}\text { Group } 2 \\
\text { Vit D deficier } \\
(n=22)\end{array}$ & & P1 & $\mathbf{P 2}$ & P3 & P4 \\
\hline $\begin{array}{l}\text { Variable } \\
(\text { mean } \pm \text { SD })\end{array}$ & $\begin{array}{l}\text { Before } \\
\text { Treatment } \\
\text { (BT) } \\
\end{array}$ & $\begin{array}{l}\text { After, } \\
\text { Treatment } \\
\text { (AT) } \\
\end{array}$ & $\begin{array}{l}\text { Before } \\
\text { Treatment } \\
\text { (BT) } \\
\end{array}$ & $\begin{array}{l}\text { After, } \\
\text { Treatment } \\
\text { (AT) } \\
\end{array}$ & $\begin{array}{l}\text { Group1 BT } \\
\text { vs AT }\end{array}$ & $\begin{array}{l}\text { Group2 } \\
\text { BT vs } \\
\text { AT }\end{array}$ & $\begin{array}{l}\text { Group 1vs } \\
\text { Group } 2 \text { for } \\
\text { BT }\end{array}$ & $\begin{array}{l}\text { Group 1 } \\
\text { vs Group 2 } \\
\text { for AT }\end{array}$ \\
\hline $\begin{array}{l}\text { Vit. D } \\
\text { Level } \\
(\mathrm{ng} / \mathrm{mL})\end{array}$ & $7.29 \pm 1.96$ & $19.52 \pm 4.72$ & $17.09 \pm 3.11$ & $25.62 \pm 5.35$ & $0.000^{\mathrm{b}}$ & $0.000^{\mathrm{b}}$ & $0.000^{\mathrm{a}}$ & $0.001^{\mathrm{a}}$ \\
\hline Quick Dash Score & $55.86 \pm 9.12$ & $48.77 \pm 8.95$ & $51.55 \pm 8.93$ & $44.70 \pm 10.41$ & $0.000^{\mathrm{b}}$ & $0.002^{\mathrm{b}}$ & $0.148^{\mathrm{a}}$ & $0.207^{\mathrm{a}}$ \\
\hline $\begin{array}{l}\text { Quick Dash work } \\
\text { model }\end{array}$ & $46.69 \pm 11.92$ & $42.77 \pm 9.80$ & $43.58 \pm 12.50$ & $36.65 \pm 12.98$ & $0.000^{\mathrm{b}}$ & $0.000^{\mathrm{b}}$ & $0.438^{\mathrm{a}}$ & $0.114^{\mathrm{a}}$ \\
\hline $\begin{array}{l}\text { Grip strengths } \\
\text { (kg) }\end{array}$ & $20.36 \pm 5.72$ & $22.50 \pm 4.76$ & $22.86 \pm 5.58$ & $25.63 \pm 5.84$ & $0.003^{\mathrm{b}}$ & $0.000^{\mathrm{b}}$ & $0.086^{\mathrm{a}}$ & $0.026^{\mathrm{a}}$ \\
\hline $\begin{array}{l}\text { Pinch strengths } \\
(\mathrm{kg})\end{array}$ & $5.48 \pm 1.52$ & $5.43 \pm 1.50$ & $5.71 \pm 1.99$ & $6.26 \pm 1.45$ & $0.892^{\mathrm{b}}$ & $0.079^{b}$ & $0.613^{\mathrm{a}}$ & $0.030^{\mathrm{a}}$ \\
\hline VAS (morning) & $2.88 \pm 0.99$ & $2.35 \pm 0.77$ & $2.95 \pm 1.09$ & $1.91 \pm 1.31$ & $0.021^{\mathrm{d}}$ & $0.000^{\mathrm{d}}$ & $0.906^{\mathrm{c}}$ & $0.930^{\mathrm{c}}$ \\
\hline VAS (Night) & $5.35 \pm 1.06$ & $4.59 \pm 0.80$ & $5.41 \pm 1.14$ & $4.05 \pm 1.53$ & $0.012^{\mathrm{d}}$ & $0.000^{\mathrm{d}}$ & $0.342^{\mathrm{c}}$ & $0.325^{\mathrm{c}}$ \\
\hline $\begin{array}{l}\text { Mild CTS } \\
(n, \%)\end{array}$ & $12(42.9)$ & $3(10.7)$ & $16(45.7)$ & $8(22.7)$ & \multirow{3}{*}{$0.012^{\mathrm{e}}$} & \multirow{3}{*}{$0.039^{\mathrm{e}}$} & \multirow{3}{*}{$0.821^{\mathrm{e}}$} & \multirow{3}{*}{$0.354^{\mathrm{e}}$} \\
\hline $\begin{array}{l}\text { Moderate CTS } \\
(\mathrm{n}, \%)\end{array}$ & $16(57.1)$ & $7(25.0)$ & $19(54.3)$ & $10(28.6)$ & & & & \\
\hline $\begin{array}{l}\text { İmproved CTS } \\
(\mathrm{n}, \%)\end{array}$ & & $18(64.3)$ & & $17(48.6)$ & & & & \\
\hline
\end{tabular}


There was no statistically significant difference between the two groups in terms of pretreatment and post-treatment electrophysiological findings. Only median nerve sensory amplitude (SA) and sensory conduction velocity (SCV) were increased in both groups. A statistically significant increase was found in the median nerve SA after treatment compared to before treatment in both groups ( $p=0.043$ and $p=0.017$ for Group 1 and Group 2, respectively). The increase in median nerve SCV was significant in Group 2 whereas it was not statistically significant in Group 1 ( $p=0.168$ and $p=0.036$ for Group 1 and Group 2 , respectively). Table 3 shows the changes in electrophysiological findings before and after treatment.

\section{Discussion}

Several studies have shown that patients with CTS have lower Vit D levels. While Vit D deficiency has been reported to increase the severity of pain in CTS cases in a study, low Vit D levels have been suggested to trigger CTS signs and symptoms in another study [15-17].
In a study by Nageeb et al. [18] involving 50 patients with CTS and 50 healthy individuals, in which the effects of Vit D level on CTS was investigated, the authors compared the Vit D levels of patients with severe CTS and patients with mild-to-moderate CTS and found that Vit D levels were significantly lower in those with severe CTS. There are studies indicating that Vit D has protective effects on neurons and decreases neuronal toxicity and damage by suppressing the cytokine pathway [19]. In a study by Shebab et al. [20] in 2015 investigating the effects of Vit D on peripheral neuropathy, 112 patients with type II DM accompanied by peripheral neuropathy were given 50,000 IU cholecalciferol once a week for eight weeks and the authors reported a significant increase in Vit D levels and a significant improvement in neuropathy symptom scores in the treatment group compared to the placebo group at the end of eight weeks.

In a recent study by Sacmaci et al. [21], Vit D values of patients with moderate CTS were reported to improve at the end of the third

Table 3: Comparison between the patients of the electrophsical evaluations before and after vitamin D replacement.

\begin{tabular}{|c|c|c|c|c|c|c|c|c|}
\hline \multirow{2}{*}{$\begin{array}{l}\text { Parameters } \\
\text { Variable } \\
(\text { mean } \pm \text { SD })\end{array}$} & \multicolumn{2}{|c|}{$\begin{array}{l}\text { Group } 1 \\
\text { Critical vit.D deficiency } \\
(n=17)\end{array}$} & \multicolumn{2}{|c|}{$\begin{array}{l}\text { Group } 2 \\
\text { vit.D deficiency } \\
(n=22)\end{array}$} & \multirow{2}{*}{$\begin{array}{l}\text { P1 } \\
\text { Group1 BT } \\
\text { vs AT }\end{array}$} & \multirow{2}{*}{$\begin{array}{l}\text { P2 } \\
\text { Group } 2 \\
\text { BT vs AT }\end{array}$} & \multirow{2}{*}{$\begin{array}{l}\text { P3 } \\
\text { Group 1vs } \\
\text { Group } 2 \text { for } \\
\text { BT } \\
\end{array}$} & \multirow{2}{*}{$\begin{array}{l}\text { P4 } \\
\text { Group 1 } \\
\text { vs Group } 2 \\
\text { for AT }\end{array}$} \\
\hline & $\begin{array}{l}\text { Before } \\
\text { Treatment } \\
\text { (BT) } \\
\end{array}$ & $\begin{array}{l}\text { After, } \\
\text { Treatment } \\
\text { (AT) } \\
\end{array}$ & $\begin{array}{l}\text { Before } \\
\text { Treatment } \\
\text { (BT) } \\
\end{array}$ & $\begin{array}{l}\text { After, } \\
\text { Treatment } \\
\text { (AT) } \\
\end{array}$ & & & & \\
\hline $\begin{array}{l}\text { Median Nerve } \\
\text { DML }(\mathrm{ms})\end{array}$ & $4.03 \pm 0.80$ & $4.17 \pm 0.72$ & $37.72 \pm 4.49$ & $39.14 \pm 6.02$ & $0.061^{\mathrm{c}}$ & $0.277^{\mathrm{c}}$ & $0.857^{\mathrm{b}}$ & $0.323^{b}$ \\
\hline $\begin{array}{l}\text { Median nerve } \\
\text { MA }(\mathbf{m} / \mathbf{s})\end{array}$ & $13.06 \pm 4.93$ & $12.88 \pm 4.13$ & $14.72 \pm 4.63$ & $14.50 \pm 3.73$ & $0.001^{\mathrm{d}}$ & $0.000^{\mathrm{d}}$ & $0.719^{\mathrm{a}}$ & $0.851^{\mathrm{a}}$ \\
\hline $\begin{array}{l}\text { Median } \\
\text { Nerve MCV } \\
(\mathrm{ms}) \\
\end{array}$ & $60.24 \pm 6.15$ & $57.50 \pm 6.08$ & $58.63 \pm 6.51$ & $57.77 \pm 5.07$ & $0.750^{\mathrm{d}}$ & $0.373^{\mathrm{d}}$ & $0.175^{\mathrm{a}}$ & $0.605^{\mathrm{a}}$ \\
\hline $\begin{array}{l}\text { Median Nerve } \\
\text { DSOL }(\mathrm{ms})\end{array}$ & $3.20 \pm 0.42$ & $3.24 \pm 0.47$ & $3.27 \pm 0.47$ & $3.30 \pm 0.51$ & $0.707^{\mathrm{c}}$ & $0.353^{\mathrm{c}}$ & $0.538^{b}$ & $0.771^{b}$ \\
\hline $\begin{array}{l}\text { Median Nerve } \\
\text { SA }(\mathbf{m V})\end{array}$ & $17.16 \pm 6.88$ & $18.30 \pm 6.59$ & $18.44 \pm 8.96$ & $19.34 \pm 8.91$ & $0.043^{\mathrm{d}}$ & $0.017^{\mathrm{d}}$ & $0.643^{\mathrm{b}}$ & 0.606 \\
\hline $\begin{array}{l}\text { Median Nerve } \\
\operatorname{SCV}(\mathrm{m} / \mathrm{s})\end{array}$ & $38.18 \pm 3.89$ & $39.03 \pm 3.78$ & $3.96 \pm 0.70$ & $4.03 \pm 0.75$ & $0.168^{c}$ & $0.036^{\mathrm{c}}$ & $0.841^{\mathrm{b}}$ & $0.934^{\mathrm{b}}$ \\
\hline \multicolumn{9}{|c|}{$\begin{array}{l}\text { a; Student T test was used. b; Mann-Whitney U was used. } \text {; Wilcoxon Test was used. } \text {; T test was used at the dependet groups. } \\
\text { deviation (SD) was showen. DSOL: Distal Sensory Onset Latency. DML: Distal motor latency. MCV: Motor Conduction velocity. SCV: Sensory } \\
\text { Conduction Velocity SA: sensory amplitude. MA: motor Amplitude. }\end{array}$} \\
\hline
\end{tabular}


month after replacement therapy compared to pre-treatment. Similar to this study, we found a statistically significant increase in posttreatment Vit D levels of both groups. Akyuz et al. [22] reported a significant improvement in pain and quality of life after eight-weeks of Vit $\mathrm{D}$ treatment in patients with chronic widespread pain; however, they further examined the patients electrophysiologically and did not identify any significant changes in nerve conduction studies following the Vit D supplementation. In a study by Sacmaci et al. [21] involving 50 female patients (45 wrists with mild CTS and 37 wrists with moderate CTS), an improvement was observed in both groups after treatment compared to pretreatment. Consistent with these findings, in the present study, a statistically significant improvement was observed in both day and night VAS scores of both groups after the treatment.

Measuring the grip strength in CTS cases is important for the evaluation of the patients. Gumieiro et al. [23] showed that individuals suffering from Vit D insufficiency had insufficient grip strength. In the present study, the grip strength of patients in both groups was increased after treatment and increase in Group 2 is significantly greater than in Group 1 which can be interpreted as less muscle strength loss since patients in Group 2 have higher Vit D levels. Post-treatment pinch strength was observed to decrease in Group 1, whereas it increased in Group 2; however, this increase in Group 2 was not statistically significant. While the pre-treatment QuickDASH scores were similar in both groups, there were statistically significant decreases after treatment in both groups, and there was no significant difference between the groups.

In a study investigating the effect of Vit D on peripheral neuropathy, the authors divided patients with DM accompanied by polyneuropathy into treatment and placebo groups and evaluated them electrophysiologically after eight weeks of Vit $\mathrm{D}$ treatment. The treatment group was observed to have lower values in median nerve motor and sensory distal latencies, higher values in median nerve SCV and median nerve motor and SAs, and lower values in the median nerve motor conduction velocity (MCV) compared to the placebo group. None of these differences were found to be statistically significant [20].In a study examining Vit D levels of CTS patients, Vit D levels were found to have a positive correlation with MCV and a negative correlation with distal motor latency (DML). In the same study, CTS patients were classified as mild, moderate, and severe, and patients with severe CTS were observed to have the lowest Vit D levels [18]. A similar study was conducted by Tanik et al. [24], in which the authors found a positive correlation between the severity of Vit D deficiency and the severity of CTS. In a study by Sacmaci et al. [21], involving 50 female patients (45 wrists with mild CTS and 37 wrists with moderate CTS), an improvement in nerve conduction values was reported in both groups. Shortening in median nerve distal sensory onset latency (DSOL) and an increase in SCV were found to be statistically significant in the mild CTS group. In the moderate CTS group, an increase in SA and SCV and a shortening in DML were found to be significant. In the present study, an increase was found only in the median nerve SA and SCV in both groups. A statistically significant increase was found in the posttreatment median nerve SA in both groups. It was observed that SCV showed a statistically significant increase only in Group 2. The positive effect of Vit $\mathrm{D}$ on both myelinization and axonogenesis, which has been shown in 
animal studies, is compatible with the results presented here $[6,25]$. However, we attribute the presence of a more significant increase in SCV only in Group 2 to the fact that the patients in this group have higher Vit D levels. In Group 1 with lower Vit D levels, mild and moderate CTS rates were $42.9 \%$ and $57.1 \%$, respectively, whereas these rates were found to be $45.7 \%$ and $54.3 \%$ in Group 2, respectively. This difference between the two groups was not statistically significant. Post-treatment findings were found to be normal in $10.7 \%$ of Group 1 and $22.7 \%$ of Group 2. Similarly, the reason for the higher rate of normal findings in Group 2 may be that the patients in this group have higher Vit D levels.

One of the important limitations of this study is that as required by routine treatment, all patients were given hand-wrist splint in addition to Vit D replacement therapy. The absence of a control group that obtained either a hand-wrist splint or a placebo group makes evaluating the efficacy of Vit D difficult. Furthermore, the inclusion of a small number of patients and a short follow-up period are other limitations. There is a need for studies with longer follow-up periods, particularly for electrophysiological evaluations.

\section{Conclusions}

In CTS patients with low Vit D levels, Vit D replacement therapy can reduce symptoms and improve functional status, as well as electrophysiological findings. When the subgroups are evaluated according to the severity of Vit D deficiency, those with higher Vit D levels show more improvement in terms of pain, functional status, and electrophysiological findings. Prospective randomized-controlled trials with longer treatment and follow-up periods, in which the efficacy of Vit D in CTS patients is evaluated are needed.
Funding: The author(s) received no financial support for the research, authorship, and/or publication of this article.

Conflict of Interest: The authors declare that they have no conflict of interest.

\section{Ethical statement:}

The study was approved by Local Clinical Research Ethics Committee (Decision number 5/1, Date 08/03/2018, and Research number 2018-030), and written informed consent was obtained from each subject.

\section{Open Access Statement}

This is an open access journal which means that all content is freely available without charge to the user or his/her institution under the terms of the Creative Commons Attribution NonCommercial License (http://creativecommons.org/licenses/bync/4.0). Users are allowed to read, download, copy, distribute, print, search, or link to the full texts of the articles, without asking prior permission from the publisher or the author.

\section{References}

[1]Lee MH, Gong HS, Lee MH, et al. The Effect of Vitamin D Deficiency Correction on the Outcomes in Women After Carpal Tunnel Release. J Hand Surg. 2019;44(8):649-54.

[2]Afşar Sİ, Sarıfakıoğlu B, Yalbuzdağ ŞA. Karpal Tünel sendromu tedavisinde fizik tedavi modalitelerinin yeri: Derleme. Turkish J Osteoporosis. 2014;20(3):125-31.

[3]Ren Y-M, Wang X-S, Wei Z-J, et al. Efficacy, safety, and cost of surgical versus nonsurgical treatment for carpal tunnel syndrome: a systematic review and metaanalysis. Medicine. 2016;95(40):e4857.

[4]Hastaliklari Mk. Osteoporoz Ve Metabolik Kemik Hastaliklari Tani Ve Tedavi Kilavuzu. 2016. 
[5]DeLuca G, Kimball S, Kolasinski J, et al. the role of vitamin $\mathrm{D}$ in nervous system health and disease. Neuropathol Appl Neurobiol. 2013;39(5):458-84.

[6]Chabas J, Stephan D, Marqueste T, et al. Cholecalciferol (Vitamin D3) Improves Myelination and Recovery after Nerve. 2013. PLOS ONE 8(5): e65034.

[7]Jablecki C, Andary M, Floeter M, et al. Practice parameter: electrodiagnostic studies in carpal tunnel syndrome: report of the American Association of Electrodiagnostic Medicine, American Academy of Neurology, and the American Academy of Physical Medicine and Rehabilitation. Neurology. 2002;58(11):1589-92.

[8]Dogan SK, Ay S, Evcik D, et al. Adaptation of Turkish version of the questionnaire Quick Disability of the Arm, Shoulder, and Hand (Quick DASH) in patients with carpal tunnel syndrome. Clinical rheumatology. 2011;30(2):185-91.

[9]Gummesson C, Ward MM, Atroshi I. The shortened disabilities of the arm, shoulder and hand questionnaire (Quick DASH): validity and reliability based on responses within the full-length DASH. BMC Musculoskeletal Disorders. 2006;7(1):1-7.

[10]Narin S, Demirbüken İ, Özyürek S, et al. Dominant el kavrama ve parmak kavrama kuvvetinin önkol antropometrik ölçümlerle ilişkisi. Dokuz Eylül Üniversitesi Tıp Fakültesi Dergisi. 2009;23(2):81-85.

[11] Mathiowetz V, Kashman N, Volland G, et al. Grip and pinch strength: normative data for adults. Arch Phys Med Rehabil. 1985;66(2):69-74.

[12]Bircan C, El O, Akalin E, et al. Functional outcome in patients with zone $\mathrm{V}$ flexor tendon injuries. Arch Orthop Trauma Surg. 2005;125(6):405-9.
[13] Medicine AAoE. AAEM Practice topic in electrodiagnostic medicine. Muscle Nerve. 2002;25:918-22.

[14]Preston DC, Shapiro BE. Electromyography and neuromuscular disorders e-book: clinical-electrophysiologic correlations (Expert Consult-Online): Elsevier Health Sciences; 2012.

[15]Demiryurek B, Gundogdu A. The effect of vitamin $\mathrm{D}$ levels on pain in carpal tunnel syndrome. Orthop Traumatol Surg Res. 2017;103(6):919-22.

[16] Gürsoy AE, Bilgen HR, Dürüyen $H$, et al. The evaluation of vitamin $D$ levels in patients with carpal tunnel syndrome. Neurological Sciences. 2016;37(7):1055-61.

[17]Lee SH, Gong HS, Kim D, et al. Evaluation of vitamin D levels in women with carpal tunnel syndrome. J Hand Surg. (European Volume). 2016;41(6):643-7.

[18] Nageeb RS, Shehta N, Nageeb GS, et al. Body mass index and vitamin $\mathrm{D}$ level in carpal tunnel syndrome patients. Egypt $\mathbf{J}$ Neurol Psychiatr Neurosurg. 2018;54(1):17.

[19] Chabas J-F, Alluin O, Rao G, et al. Vitamin D2 potentiates axon regeneration. $J$ Neurotrauma. 2008;25(10):1247-56.

[20] Shehab D, Al-Jarallah K, Abdella N, et al. Prospective evaluation of the effect of shortterm oral vitamin D supplementation on peripheral neuropathy in type 2 diabetes mellitus. Med Princ Pract. 2015;24(3):2506.

[21] Sacmaci H, Tanik N, Balbaloğlu Ö, et al. Electrophysiological evaluation of carpal tunnel syndrome female patients after vitamin D replacement. Arq Neuropsiquiatr. 2020;78(4):224-9.

[22] Akyuz G, Sanal-Toprak C, Yagci I, et al. The effect of vitamin D supplementation on pain, quality of life, and nerve conduction 
studies in women with chronic widespread pain. Int J Rehabil Res. 2017;40(1):76-83.

[23] Gumieiro DN, Rafacho BPM, Pereira BLB, et al. Vitamin D serum levels are associated with handgrip strength but not with muscle mass or length of hospital stay after hip fracture. Nutrition. 2015;31(7-8):931-34.

[24] Tanik N, Balbaloğlu Ö, Ucar M, et al. Does vitamin $\mathrm{D}$ deficiency trigger carpal tunnel syndrome? J Back Musculoskelet Rehabil. 2016;29(4):835-39.

[25] Montava M, Garcia S, Mancini J, et al. Vitamin D3 potentiates myelination and recovery after facial nerve injury. Eur Arch Otorhinolaryngol Suppl. 2015;272(10):2815-23. 